\title{
Low Pressure Storage of Natural Gas for Vehicular Applications
}

Tim Burchell and Mike Rogers Oak Ridge National Lab. 
SAE routinely stocks printed papers for a period of three years following date of publication. Direct your orders to SAE Customer Sales and Satisfaction Department.

Quantity reprint rates can be obtained from the Customer Sales and Satisfaction Department.

To request permission to reprint a technical paper or permission to use copyrighted SAE publications in other works, contact the SAE Publications Group.

This article was prepared as an account of work sponsored by an agency of the United States

Government. Neither the United States Government nor any agency thereof, nor any of their employees, makes any warranty, express or implied, or assumes any legal liability or responsibility for the accuracy, completeness, or usefulness of any information, apparatus, product, or process disclosed, or represents that its use would not infringe privately owned rights. Reference herein to any specific commercial product, process, or service by trade name, trademark, manufacturer, or otherwise does not necessarily constitute or imply its endorsement, recommendation, or favoring by the United States Government or any agency thereof. The views and opinions of authors expressed herein do not necessarily state or reflect those of the United States Government or any agency thereof.

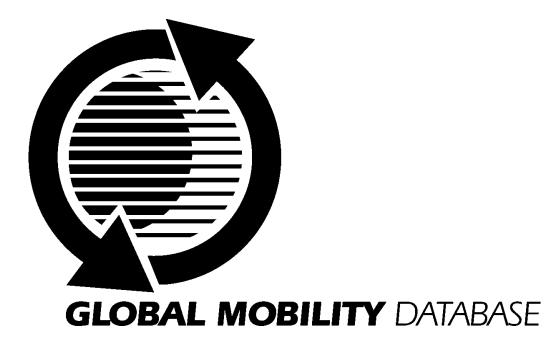

All SAE papers, standards, and selected books are abstracted and indexed in the Global Mobility Database

ISSN 0148-7191

No copyright is asserted in the works of U.S. Government employees.

Positions and opinions advanced in this paper are those of the author(s) and not necessarily those of SAE. The author is solely responsible for the content of the paper. A process is available by which discussions will be printed with the paper if it is published in SAE Transactions. For permission to publish this paper in full or in part, contact the SAE Publications Group.

Persons wishing to submit papers to be considered for presentation or publication through SAE should send the manuscript or a 300 word abstract of a proposed manuscript to: Secretary, Engineering Meetings Board, SAE.

\section{Printed in USA}




\title{
Low Pressure Storage of Natural Gas for Vehicular Applications
}

\author{
Tim Burchell and Mike Rogers \\ Oak Ridge National Lab.
}

No copyright is asserted in the works of U.S. Government employees

\begin{abstract}
Natural gas is an attractive fuel for vehicles because it is a relatively clean-burning fuel compared with gasoline. Moreover, methane can be stored in the physically adsorbed state [at a pressure of $3.5 \mathrm{MPa}(500 \mathrm{psi})$ ] at energy densities comparable to methane compressed at $24.8 \mathrm{MPa}(3600 \mathrm{psi})$. Here we report the development of natural gas storage monoliths [1]. The monolith manufacture and activation methods are reported along with pore structure characterization data. The storage capacities of these monoliths are measured gravimetrically at a pressure of $3.5 \mathrm{MPa}(500 \mathrm{psi})$ and ambient temperature, and storage capacities of $>150 \mathrm{~V} / \mathrm{V}$ have been demonstrated and are reported.
\end{abstract}

\section{INTRODUCTION}

Methane (the major constituent of natural gas) has a higher $\mathrm{H} / \mathrm{C}$ ratio than any other fuel, and consequently a higher Research Octane No. than other fuels (130 compared to 87 for unleaded gasoline). Unfortunately, methane cannot be stored at a density as high as other fuels, and thus has an energy density approximately one-third that of gasoline $(11 \mathrm{MJ} / \mathrm{L}$ for compressed natural gas at 24.8 MPa (3600 psi) compared with $32 \mathrm{MJ} / \mathrm{L}$ for gasoline). Thus a compressed natural gas (CNG) fuel tank would need to be approximately three times larger than a gasoline tank to allow a vehicle the same driving range. The use of CNG has its disadvantages. The CNG storage tanks must be pressure vessels and are thus constrained in their geometry (they are typically cylindrical), and are also rather heavy ( $\approx 1 \mathrm{~kg} / \mathrm{L}$ for steel tanks). Moreover, attainment of $>20.7 \mathrm{MPa}$ (3000 psi) pressure requires costly multi-stage compression.

For these reasons the US Department of Energy has pursued a research program aimed at the development of suitable materials for the storage of natural gas in the physically adsorbed state. Adsorbed natural gas (ANG) is conventionally stored in porous carbon materials at a gas pressure of $3.5 \mathrm{MPa}(500 \mathrm{psi})$. This lower storage pressure reduces the cost of the storage vessel, allows the use of single stage compressors, and represents a lesser safety hazard than the higher pressures used for CNG. The DOE storage target for ANG has been set at $150 \mathrm{~V} / \mathrm{V}$, i.e., $150 \mathrm{STP}(101.325 \mathrm{KPa}, 298 \mathrm{~K})$ liters of gas stored per liter of pressure vessel internal volume.

A novel adsorbent carbon monolith based on carbon fibers has been developed at the Oak Ridge National Laboratory (ORNL) and offers a solution to the limitations of conventional activated carbons for ANG applications. Because of its monolithic nature the material is abrasion resistant. Moreover, the continuous carbon skeleton allows for the liberation of practically all of the adsorbed gas via low-voltage electrical stimulation. Similarly, the continuous carbon skeleton of our monoliths offers enhanced thermal conductivity over packed beds of carbon. This translates to smaller temperature gradients during tank charging and discharging. The development of storage monoliths has been ongoing at ORNL for the past three years, and we recently attained storage capacities in excess of the DOE target of $150 \mathrm{~V} / \mathrm{V}$. With continued process development and materials optimization it is anticipated that storage capacities of $>180 \mathrm{~V} / \mathrm{V}$ (delivered) can be attained - giving approximately one-fourth the driving range of an equivalent volume gasoline tank.

\section{EXPERIMENTAL}

Gas storage monoliths were fabricated from isotropic pitch-derived carbon fibers (Carboflex fibers, Anshan East Asia Carbon Company, Anshan, China) and a powdered phenolic resin (Durez grade 7716, Occidental Chemical Corp., N. Tonanwanda, NY 14120, USA). A schematic diagram of the fabrication route is in Figure 1. The monoliths were hot-pressed to densities in the range $0.7-0.92 \mathrm{~g} / \mathrm{cm}^{3}$, and carbonized prior to activation in a $\mathrm{CO}_{2}$ atmosphere to the desired burn-off. Post activation analysis of the monoliths included micropore characterization via $\mathrm{N}_{2}$ adsorption at $77 \mathrm{~K}$, and bulk density determination by mensuration. Methane uptake was measured at room temperature and $500 \mathrm{psi}$ on $50-\mathrm{cm}^{3}$ volume samples using the apparatus pictured in Figure 2. 


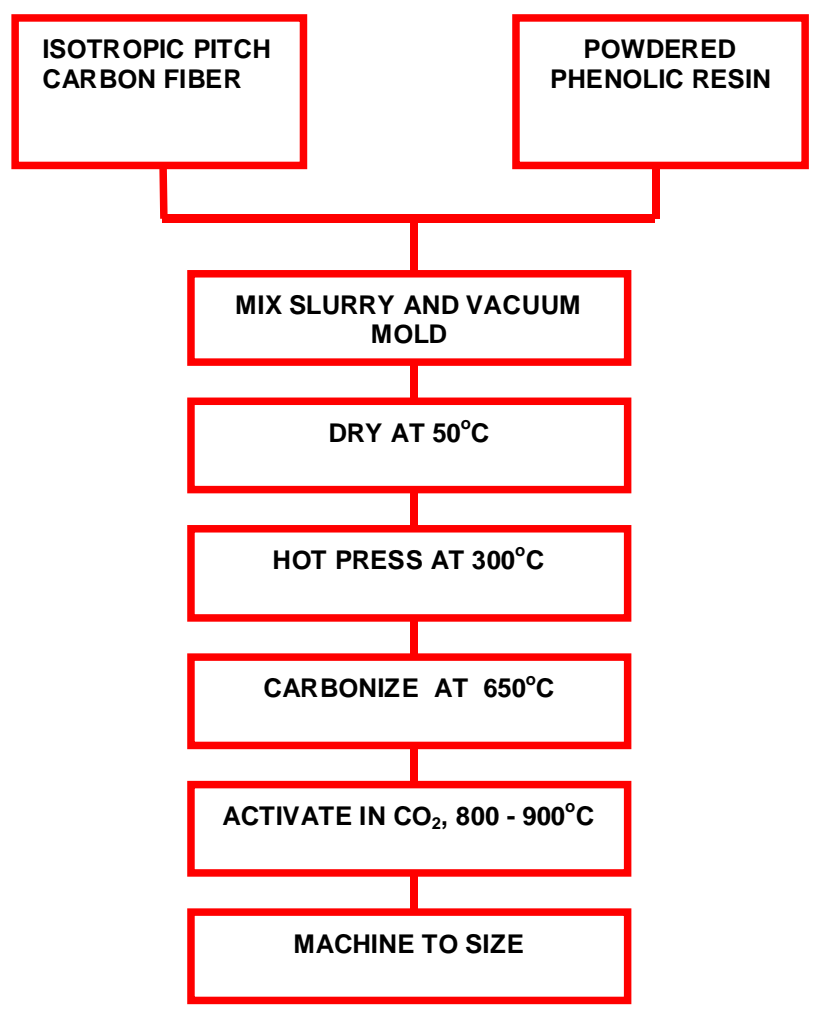

The standard monolith size (as manufactured) was $~ 115$ $\mathrm{mm}$ (4.5 inches) diameter and $38 \mathrm{~mm}$ (1.5 inches) thick. From this part a series of smaller samples [ $23 \mathrm{~mm}(0.9$ inch) diameter] were machined (Figure 3 ) for testing in the gravimetric apparatus. The test samples were stacked in the test cell to completely fill the $50 \mathrm{~cm}^{3}$ test cylinder cavity. The storage samples were vacuum outgassed at $473 \mathrm{~K}$ in the test cylinder, cooled to ambient temperature, and then slowly filled (near isothermal) to 3.5 MPa (500 psi) pressure. The storage capacity and carbon activity was then calculated from the cylinder's mass gain on charging.

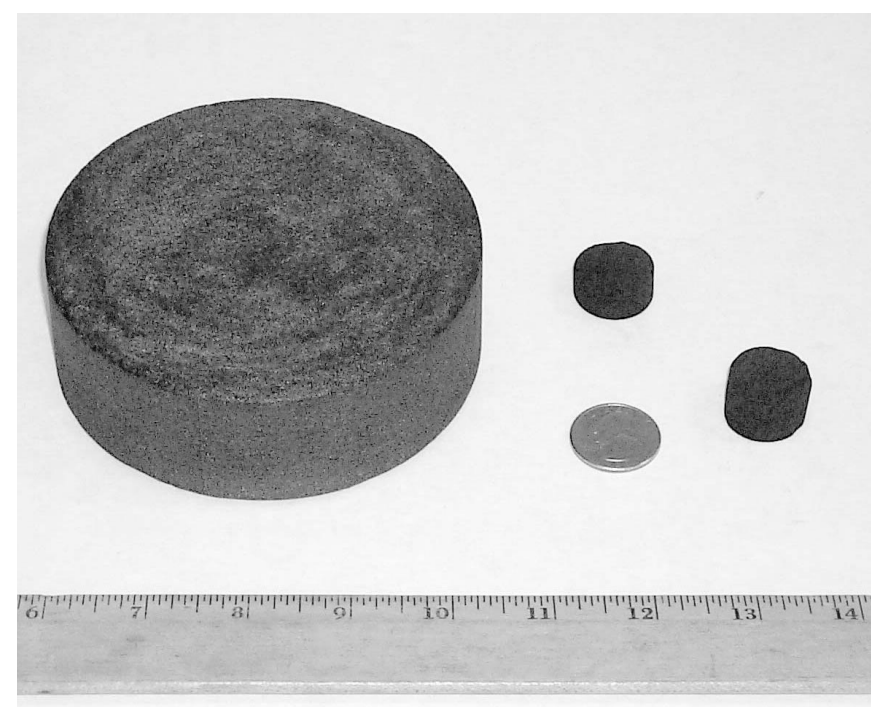

Figure 3. Gas storage monolith and test specimens

\section{RESULTS AND DISCUSSION}

The results of our recent micropore characterization and gas storage studies are reported in Tables 1 and 2. A storage capacity of $150 \mathrm{~V} / \mathrm{V}$ at $3.5 \mathrm{MPa}$ (500 psi) and $294 \mathrm{~K}$ has been attained, which is comparable to the best commercially available gas storage carbons [2]. The storage capacity is temperature sensitive. For example, the storage capacity of sample SMS-22 was $150 \mathrm{~V} / \mathrm{V}$ at 294K, but increases to $159 \mathrm{~V} / \mathrm{V}$ at $285 \mathrm{~K}$ (Fig. 4).

Activation of the monoliths (burn-off) results in the development of microporosity, as indicated by the BET and micropore volume data in Table 1. Increasing the degree of burn-off increases the micropore volume and the mean micropore size (Figs. 5 and 6). Although increased micropore volume is beneficial, since the gas is adsorbed into the micropores, it is so only to a point. At very large burn-off the density of the monolith is small, and the mean micropore size becomes large and far from the optimum value of $1.12 \mathrm{~nm}$ [3]. Consequently, excessive burn-off is not productive.

Figure 2. Methane adsorption test apparatus 
Table 1. Micropore characterization data for our methane storage monoliths

\begin{tabular}{|c|c|c|c|c|}
\hline Sample & $\begin{array}{c}\text { Burn-off } \\
(\%)\end{array}$ & $\begin{array}{c}\text { BET Area } \\
\left(\mathrm{m}^{2} / \mathrm{g}\right)\end{array}$ & $\begin{array}{l}\text { DR Micropore } \\
\text { Volume } \\
\left(\mathrm{cm}^{3} / \mathrm{g}\right)\end{array}$ & $\begin{array}{l}\text { DR Micropore } \\
\text { Width } \\
(\mathrm{nm})\end{array}$ \\
\hline SMS-15 & 55.2 & 2524 & 0.86 & 2.59 \\
\hline SMS-16 & 75.3 & 3173 & 1.09 & 2.57 \\
\hline SMS-17 & 51.9 & 2454 & 0.85 & 2.61 \\
\hline SMS-18 & 49.0 & 2237 & 0.78 & 2.49 \\
\hline SMS-19 & 55.9 & 2552 & 0.88 & 2.61 \\
\hline SMS-22 & 57.8 & 2451 & 0.84 & 2.64 \\
\hline SMS-23 & 31.8 & 1494 & 0.56 & 2.06 \\
\hline SMS-30 & 81.5 & 2860 & 0.98 & 2.68 \\
\hline
\end{tabular}

Table 2. Methane gas adsorption and storage data for our storage monoliths

\begin{tabular}{|c|c|c|c|}
\hline Sample & $\begin{array}{c}\text { Cell Pack } \\
\text { Density } \\
\left(\mathbf{g} / \mathbf{c m}^{3}\right)\end{array}$ & $\begin{array}{c}\text { Methane } \\
\text { Activity } \\
(\mathbf{\%})\end{array}$ & $\begin{array}{c}\text { Storage } \\
\text { Capacity } \\
(\mathbf{V} / \mathbf{V})\end{array}$ \\
\hline SMS-15 & 0.57 & 11.8 & 128 \\
\hline SMS-16 & 0.48 & 11.6 & 111 \\
\hline SMS-17 & 0.56 & 11.6 & 124 \\
\hline SMS-18 & 0.53 & 11.4 & 118 \\
\hline SMS-19 & 0.65 & 12.7 & 149 \\
\hline SMS-22 & 0.63 & 13.2 & 150 \\
\hline SMS-23 & 0.70 & 8.3 & 112 \\
\hline SMS-30 & 0.39 & 15.4 & 120 \\
\hline
\end{tabular}

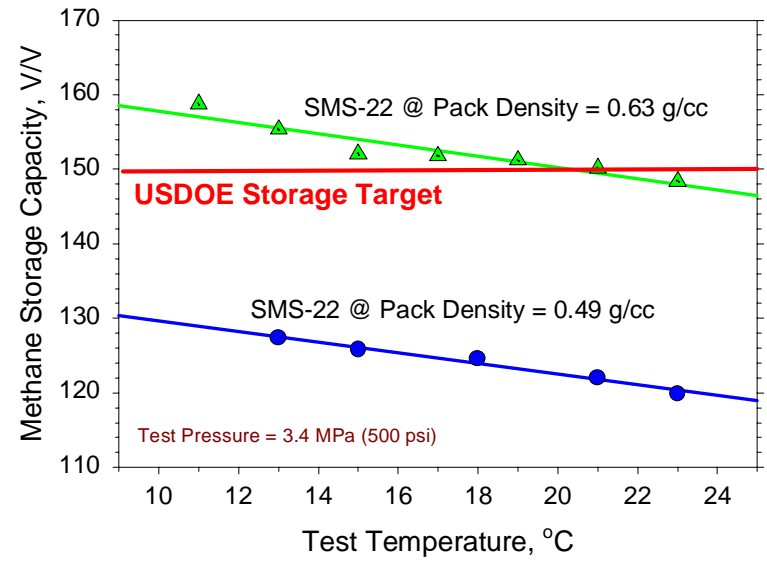

Figure 4. The variation of methane storage capacity with ambient temperature

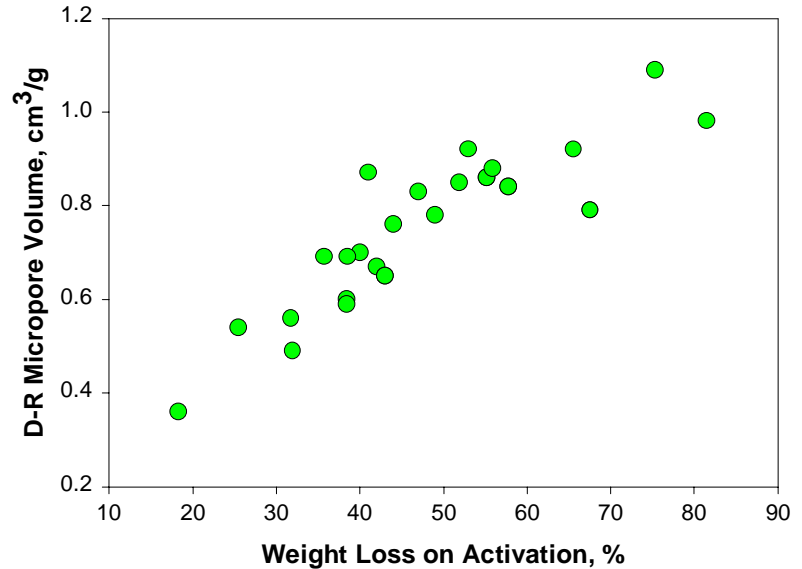

Figure 5. The variation of micropore volume with monolith burn-off

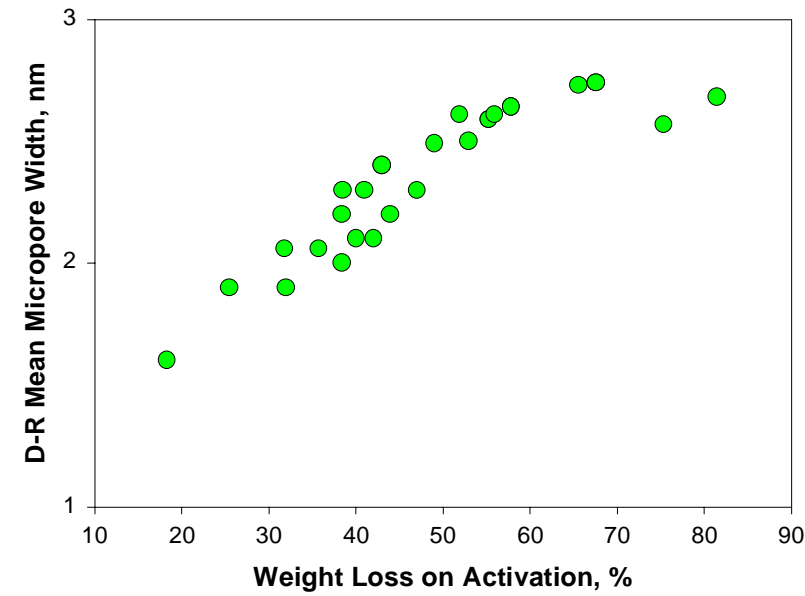

Figure 6. The variation of mean micropore size with monolith burn-off

This point is illustrated by the data for samples SMS-23 and SMS-30 (Tables 1 and 2). In the former, the density is large but the methane activity is rather low and the resultant capacity was only $112 \mathrm{~V} / \mathrm{V}$. In the latter case, the activity was much greater (15.4 cf. $8.3 \%$ ), but the density is extremely low $\left(0.39 \mathrm{cf} .0 .7 \mathrm{~g} / \mathrm{cm}^{3}\right)$, and the resultant capacity is not greatly improved. The optimum storage monolith is, therefore, one which exhibits high methane activity (which is a function of micropore size and total micropore volume) and high density. Such a monolith might be expected to store as much as $180 \mathrm{~V} / \mathrm{V}$ of methane at $3.5 \mathrm{MPa}(500 \mathrm{psi})$ - the revised DOE target storage capacity. 
The attainment of a methane storage capacity of $180 \mathrm{~V} / \mathrm{V}$ is particularly significant, since at that level comparable energy densities to compressed natural gas at $24.8 \mathrm{MPa}$ (3600 psi) are achieved. Our anticipated progress toward demonstrating a storage capacity of $180 \mathrm{~V} / \mathrm{V}$ is shown in Figure 7 below.

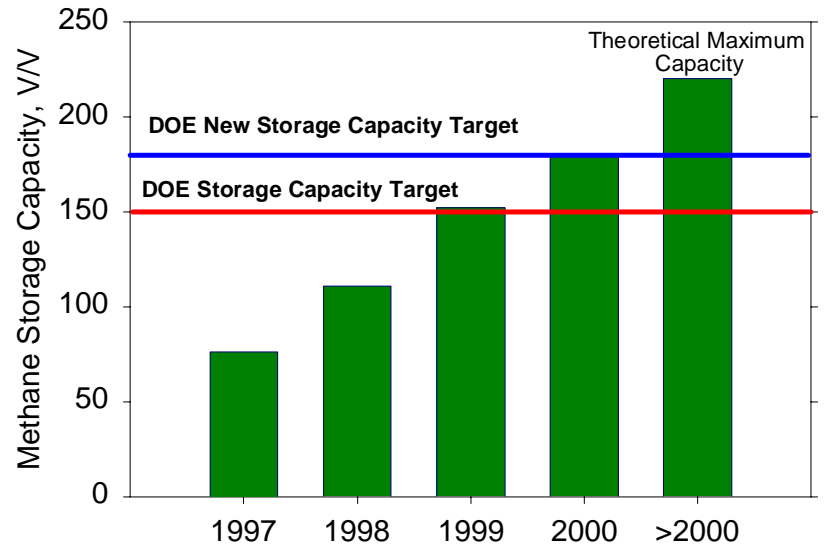

Figure 7. Methane storage capacities of ORNL's novel monoliths

A unique feature of our monoliths is worthy of discussion. The material exhibits a continuous carbon skeleton (Figure 8 ) and thus exhibits superior thermal conductivity and is electrically conductive. This latter phenomenon enables all of the adsorbed gas to be delivered by electrically stimulating desorption of the gas.

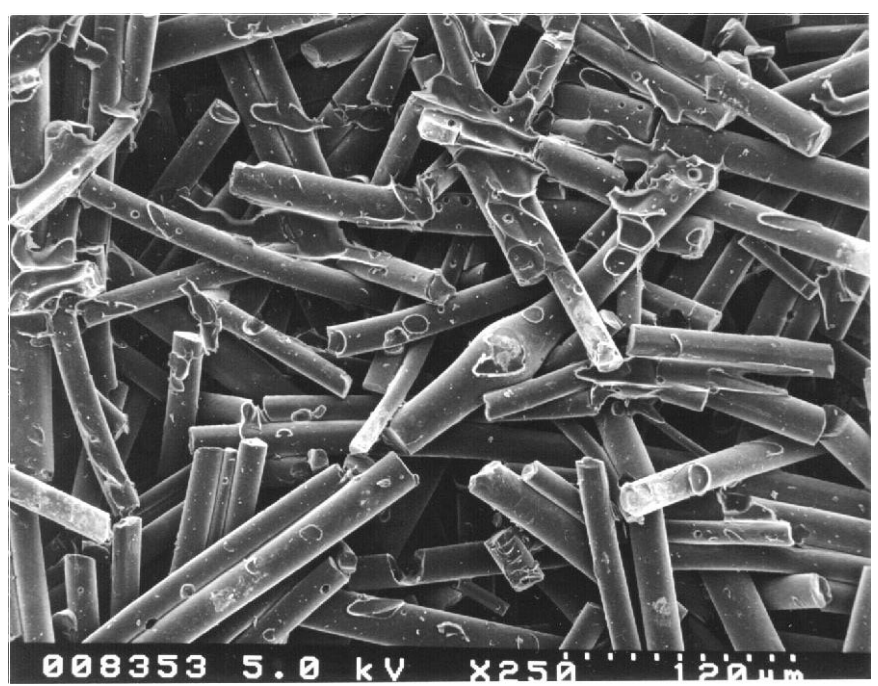

Figure 8. The microstructure of ORNL's novel gas storage monolith

Typically, $10-20 \%$ of the gas adsorbed into the monolith is retained when the gas pressure is reduced to one atmosphere. This is illustrated in Figure 9, where the uptake of methane is shown for a repetitive charge/discharge cycle. In the first cycle the cylinder is charged from vacuum to $3.5 \mathrm{MPa}$ (500 psi) under near isothermal condi- tions. When the gas is released and the pressure drops to atmospheric pressure some fraction of the adsorbed gas is retained in the carbon. As the data in Figure 9 indicates, the amount of gas retained does not appear to increase as the adsorbent is cycled. However, the amount of delivered gas is less than the total amount stored. The use of electrical stimulation to desorb the adsorbed gas (4) allows all of the adsorbed gas to be delivered, thus increasing the range of a vehicle fuelled from an adsorbed natural gas tank.

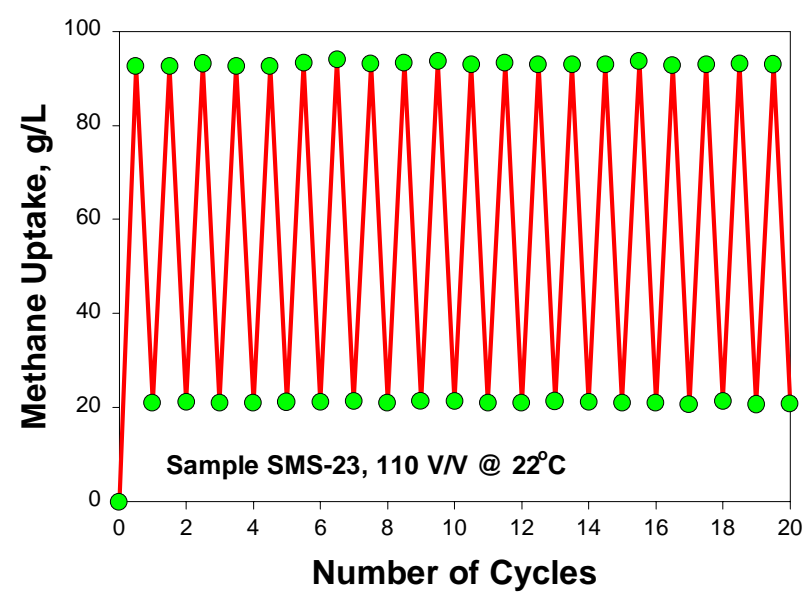

Figure 9. Methane uptake of an ORNL storage monolith over several cycles of charge and discharge

Enhanced thermal conductivity is also advantageous during rapid methane charge and discharge situations. Since the adsorption of methane onto activated carbon is an exothermic process, the adsorbent heats during adsorption. Similarly, desorption of methane is an endothermic process and, therefore, the adsorbent temperature drops as the gas is desorbed. The extent of these temperature changes is illustrated in Figure 10 for a fast charge/discharge of our standard $50-\mathrm{cm}^{3}$ monolith filled test cylinder. These temperature changes have design implications and, therefore, minimizing the temperature changes is particularly important. The amount of gas adsorbed decreases as the temperature increases. Therefore, on filling, the capacity of the tank is diminished by the rise in adsorbent temperature and it is necessary to overpressurize the tank to achieve the desired storage capacity. When the adsorbent cools the gas pressure drops to the working pressure. Moreover, when the tank is discharged, the adsorbent temperature drops and the adsorbed gas is not released. Consequently, the gas pressure in the tank falls and the gas flow to the engine may be interrupted. Enhanced thermal conductivity will tend to reduce the significance of the two phenomena. Moreover, the ability to electrically stimulate desorption of the adsorbed gas [4] offers the possibility of completely eliminating the gas pressure/supply problem associated with fast discharge. 


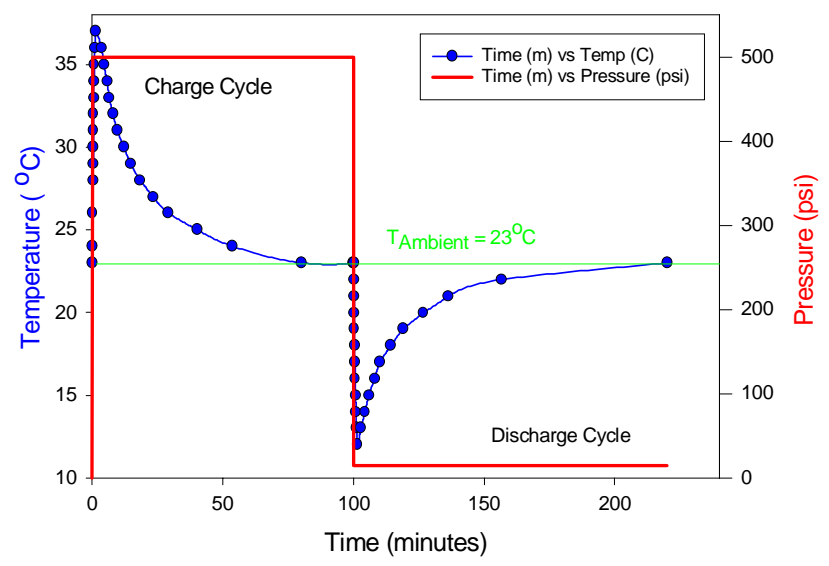

Figure 10. Variation of our methane test cylinder $\left(50 \mathrm{~cm}^{3}\right.$ volume) temperature during a fast fill/ discharge cycle

\section{CONCLUSIONS}

A novel gas storage monolith based on carbon fibers has been developed that can store and deliver $>150 \mathrm{~V} / \mathrm{V}$ of methane. The monolith is rugged and durable. Moreover, the monolith offers enhanced thermal conductivity over conventional adsorbent carbons, which will reduce the deleterious effects of temperature gradient that develop during tank charge and discharge. The monoliths are electrically conductive, allowing the liberation of all of the adsorbed gas and maximizing the amount of gas delivered to the engine. It is anticipated that the revised methane storage capacity of $180 \mathrm{~V} / \mathrm{V}$ will be attained in the near future.

\section{ACKNOWLEDGMENTS}

Research sponsored by Oak Ridge National Laboratory, managed by UT-Battelle, LLC, for the U.S. Dept. of Energy under contract DE-AC05-00OR22725.

\section{REFERENCES}

1. Burchell, T.D., Klett, J.W., and Rogers, M.R., In Proc. CARBON'98, 1998, 671.

2. Baker, F.S., U.S. Patent No. 5,710,092, Jan. 20, 1998.

3. Tan, Z. and Gubbins, K.E., J. Phys Chem. 1992, 94, 6061.

4. Burchell, T.D., Judkins, R.R., Rogers, M.R., and Williams A.M., CARBON 1997, 35, 1279.

\section{CONTACT}

Dr. Tim Burchell

Tel: (865) 576-8595

Fax: (865) 576-8424

E-mail BurchellTD@ornl.gov 